\title{
Making the Real: Rhetorical Adduction and the Bangladesh Liberation War
}

\author{
Joseph O’Mahoney
}

\begin{abstract}
Do normative arguments change what political actors do and if so, how? Rather than using the pure force of abstract moral reasoning, states often try to move the locus of contestation to an arena where they can make practical progress - the evidence or the empirical facts in support of their argument. This paper analyzes how states try to bolster their position first by constructing an argument in which an action represents part of their argument and then by performing that action to make the argument seem more convincing. I call this mechanism rhetorical adduction. The paper challenges theories of communication that deny a causal role to the content of normative arguments and diverges from a leading view on argumentation that arguments have their effects through persuasion. Integrating strategic argumentation theory with theory from psychology about how people make choices based on compelling reasons rather than cost-benefit analysis, I also use theory from sociology on how people resolve morally complex situations through the performance of "reality tests." I illustrate the mechanism using a case from the Indo-Pakistani war of 1971 when initial resistance to recognizing the putative state of Bangladesh after India's invasion of East Pakistan was reversed as a result of an argument that Indian troop withdrawal meant that international norms were not violated.
\end{abstract}

In 1971, India invaded Pakistan and used the ensuing military victory to create a new state out of a large chunk of Pakistani territory. India's actions were widely criticized. For example, speaking to the UN Security Council, US Ambassador to the UN George Bush described the invasion as "force in violation of the United Nations Charter." "Speaking to the press on behalf of the US government, he called the invasion "aggression" against Pakistan. ${ }^{2}$ A UN General Assembly resolution taking an anti-India position was passed overwhelmingly, 104 to $11 .^{3}$ India, and others

Thanks for a variety of different forms of assistance to Robert Adcock, Davy Banks, Samuel Barkin, Zoltan Buzas, Henry Farrell, Tine Hanrieder, Markus Kornprobst, Paul Kowert, Ron Krebs, Eric Lawrence, Julia MacDonald, Brian Muzas, participants at International Studies Association North-East 2013, American Political Science Association 2014, the Seton Hall University School of Diplomacy Faculty Seminar, the Seton Hall University Research Council, two anonymous reviewers, and the editors of International Organization.

1. United Nations Security Council Official Records, S/PV.1606, 4 December 1971, 194. Available at $<$ http://dag.un.org/handle/11176/74490>.

2. Bernard Gwertzman, "White House Says Vote in UN Supports Its Stand: But It Is Seeking to Assuage India; Ziegler Says Assembly Step Is Not Seen as Condemning Anyone in the Conflict," New York Times, 9 December 1971, 17.

3. With ten abstentions. See United Nations General Assembly, Resolution 2793 (26), 7 December 1971. 
including the USSR, counter-argued, claiming that India's use of force was a humanitarian intervention. Recognition of the proposed new state called Bangladesh was initially opposed and resisted, with reasons including that it would violate international law, that such recognition would "guarantee the fruits of aggression," and that the new state did not command enough loyalty. A request to invite representatives of Bangladesh to the Security Council was denied because a new state with the necessary criteria for recognition did not exist. ${ }^{5}$ Two proposed Security Council resolutions rejecting the transfer of political authority to Bangladesh were defeated by a Soviet veto. Soviet-drafted resolutions including "recognition [of] the will of the East Pakistan population, as expressed, clearly and definitely, in ... elections" were rejected. ${ }^{6}$ Despite this initial widespread condemnation, several months after the Indian invasion, dozens of states recognized Bangladesh and accepted it as a new member of the international community. How did states reconcile this contradiction? Why did states that initially firmly rejected giving authority to a new state in East Pakistan turn around and recognize Bangladesh?

This puzzle is just one instance of international actors arguing over their actions and policies and those of their opponents. States often disagree about a policy that requires the consent or participation of the rest of the international community and so try to win over the undecided. As well as using bribery and coercive threats, states try to make the policy seem useful, good, or legitimate. ${ }^{7}$ That is, they make normative arguments. Their goal is to make arguments that are as convincing as possible. ${ }^{8}$ Of course, at the same time, the opposing group of states is attempting the same thing. Arguments are met with counter-arguments. But do such arguments have any influence on the overall outcome? Normative argumentation can be powerful but only if your version wins out over the opponents'. What makes one argument better than another?

States have a particular way of trying to win normative arguments. Rather than using the pure force of abstract moral reasoning, states try to move the locus of contestation to an arena where they can make practical progress - the evidence or the empirical facts in support of their argument. It is not given by nature what facts are relevant to normative arguments and so there are two things states can do that might allow them to manipulate an audience's attitude toward a policy. First, states can reach into the intersubjective collection of ideas, symbols, and rhetorical

4. United Nations Security Council Official Records, S/PV.1608, 6 December 1971, 104. Available at $<$ http://dag.un.org/handle/11176/74492>.

5. Ibid., S/PV.1613, 13 December 1971, 93 and 134. Available at <http://dag.un.org/handle/11176/ $74497>$.

6. Ibid., S/PV.1608, 6 December 1971, 52.

7. This is the basis of the argumentation and rhetorical action literatures. See Bjola and Kornprobst 2011; Krebs and Jackson 2007; Risse 2000; Schimmelfennig 2001.

8. What makes an argument convincing may not conform to an abstract definition of rationality. See, for example, Kuhn 1991 for evidence that people change their minds on formally fallacious grounds, like the provision of a single example, mere elaboration of a possible causal pathway, or even pointing out the negative effects of a behavior as proof that it does not occur. 
commonplaces ${ }^{9}$ and link together some empirical fact and some part of their normative argument. In particular, they might be able to define the empirical fact such that it is the result of, or constituted by, an action that they can take. Second, they can take action to change the empirical situation so that it is congruent with their argument. Standard stories of manipulation include lying, ${ }^{10}$ deception,,${ }^{11}$ and costly signaling, ${ }^{12}$ but these are not the only ways of understanding what states can do. In particular, if you can remove or dilute objections to a policy by changing the normative status of that policy, then people will be less likely to oppose and more likely to support your preferred policy. One important influence on the acceptability of a normative argument is the extent to which the facts conform to the premises (explicit or implicit) of the argument. A central problem in international politics is, then, how can you make your version of reality seem more real than your opponents' version?

I analyze how states try to bolster their position by first constructing an argument in which a particular action represents or manifests part of the argument, and then by performing that action to make the argument seem more convincing. This process I call rhetorical adduction. ${ }^{13}$ The paper challenges IR theories of communication that deny a causal role to the content of normative arguments. It also diverges from a leading view in the literature on argumentation and rhetorical action on how arguments have their effects and instead builds an alternative framework that integrates strategic argumentation theory from IR with theory from psychology about how people make choices based on compelling reasons rather than costbenefit analysis, as well as theory from sociology about how people resolve morally complex situations through the performance of "reality tests." 14

Specifically, I investigate the peace-making process after the 1971 Indo-Pakistani war, or the Bangladesh Liberation War. I argue that the recognition of the new state of Bangladesh and the withdrawal of Indian troops from Bangladeshi territory were both driven by rhetorical adduction. States were not already inclined to recognize Bangladesh because of the intense political violence in East Pakistan and recognition decisions were not uncontested and regularized applications of international law. Further, India's withdrawal was not a result of high occupation costs (or the expectation thereof) or other Bangladeshi resistance. Instead, recognition was made possible by the argument that the withdrawal of Indian troops from Bangladesh meant that recognizing Bangladesh would not violate norms of non-aggression, self-determination, or the international legal norm of effective control of territory, and withdrawal was aimed at bolstering that argument.

9. Crawford 2002; and Krebs and Jackson 2007.

10. Mearsheimer 2011.

11. Reiter 2012.

12. Fearon 1997.

13. Adduction is an act of adducing and to adduce something is to offer, cite, or provide it as evidence in support of an argument.

14. Boltanski and Thevenot 2006, 40. 


\section{How Do Arguments Have Their Effects?}

The current literature on the role of argumentation can be divided into three categories according to the types of effects they understand arguments to have. ${ }^{15}$ The leading two approaches are based on a model of action in which actors have a set of preferences (complete and transitive). Rationalist models do not allow for arguments to change preferences (although they might reveal information that would change beliefs). ${ }^{16}$ Persuasionists allow for arguments to be causal, but believe that the only causally relevant effect arguments have is to change preferences. Finnemore and Sikkink define persuasion as the effective attempt by advocates to "change the utility functions of other players to reflect some new normative commitment."17 Once changed, preferences interact with beliefs to produce action different from what would have happened without the argument. An influential example of persuasionism is Risse's seminal account of the "logic of arguing," a third alternative to strategic, utility-maximizing, action and rule-guided behavior. ${ }^{18}$ This involved actors engaging in "truth seeking with the aim of reaching a mutual understanding based on a reasoned consensus." 19 However, Risse's account has several limitations. First, it cannot easily deal with rhetorical action, or the strategic use of argumentation and discourse. Following Habermas, Risse sees action as either strategic, in that preferences are fully defined and fixed and completely immune to any talk, or as arguing, where actors are willing to change their previous preferences because of the logical power of an argument. The contrast is between doing something because a more powerful actor coerces you to, and because you newly believe that this is the right thing to do. However, as Schimmelfennig and Müller point out, this distinction is untenable because rhetorical action is both strategic and concerned with argumentation. ${ }^{20}$ How can these be reconciled? One way that stays within Risse's framework is that rhetorical action can enlist both sincere agreement and also insincere acquiescence. Some actors who are under social pressure may not change their deeply held normative beliefs, or feel ashamed, but instead refrain from behavior intersubjectively constructed as illegitimate to the extent that they are concerned about their standing and reputation in the community. They might also want to leverage their reputation in later rhetorical contestation. The potential social fallout from rejecting what you think seems to other people a reasonable argument could have constraining or motivating effects. ${ }^{21}$

15. In this review I focus on only this one element of the literature. See Seymour 2014 for an alternative, more comprehensive, breakdown of the argumentation literature. An important point that I do not cover here is the distinction between an argument's effect on action and its effect on the background collection of ideas, symbols, and rhetorical commonplaces.

16. For just one example addressing this particular point, see Goldsmith and Posner 2002.

17. Finnemore and Sikkink 1998, 914.

18. Risse 2000, 2.

19. Ibid., 1; see also Deitelhoff 2009.

20. See Müller 2004, 414; and Schimmelfennig 2001, 65.

21. Hanrieder 2011, 392. 
For Risse, the crucial distinction between rhetorical and communicative action is whether the arguers are willing to change their minds or be persuaded. ${ }^{22}$ This he defines in terms of changing "interests" or "views of the world" 23 as a result of the better argument where considerations of power and hierarchy are absent. However, the second limitation of a standard persuasionist account is that this ignores the numerous ways that people's attitudes can be influenced through irrational means. Risse himself uses several examples as instances of communicative action that undercut his definition. One is that actors with "authoritative knowledge or moral authority" will be more convincing to an audience than actors with known private interests. ${ }^{24}$ If this is true, it is not because of a logical property of the better argument. The nonlogical element to the superior convincingness of an argument is an example of a whole class of influences on argumentation that is absent from Risse's schema. An alternative strand of the argumentation literature, ${ }^{25}$ as well as the strategic framing literature $^{26}$ allows for a variety of effects of discourse.

The third problem with a persuasionist account is the implicitly binary nature of the effect of argumentation. At time $t_{1}$, A prefers x over $\mathrm{y}$. Then argumentation occurs. Finally, at time $t_{2}$, A prefers y over x. But this kind of attitude change is only one possible effect of argumentation. Various other possible effects have been identified. For example, Benford and Snow identify three framing tasks: diagnostic framing for the identification of a problem and assignment of blame, prognostic framing to suggest solutions to a problem or strategies to pursue, and motivational framing that provides a rationale or call to action. ${ }^{27}$ A particular type of effect is that argumentation can change the normative status of an action. Actors vary in how much they care about normative statuses as well as any particular normative status. Normative status is not necessarily binary, such as good or bad. Instead, an act can vary from despicable through distasteful, to neutral, and then to admirable and heroic. It can also range from forbidden, through frowned upon and excused to permitted, and then to obligatory. Pushing in line has a different normative status from murder, though both are norm violations. Another important type of normative status is the difference between a clear violation and an excused exception, for example, murder and killing in self-defense. When an act appears to potentially represent a norm violation, actors attempt to justify it, both to themselves and to outside audiences. As Shannon explains, this difference often hinges on "one's ability to define a situation in a way that allows socially accepted violation." 28

22. He defines arguing as a situation in which all speakers are open to be persuaded by the better argument. See Risse 2004, 294.

23. Risse 2000, 2.

24. Ibid., 22.

25. See, for example, Bjola and Kornprobst 2011; Krebs and Jackson 2007; and Seymour 2014.

26. See, for example, Busby 2007; and Sell and Prakash 2004.

27. Benford and Snow 2000, 615.

28. Shannon 2000, 300. 
Fourth, persuasionism follows rationalism in assuming what Slovic calls "stable, well-articulated preferences," 29 that is, clearly defined prior preferences over outcomes (i.e., completeness of preferences). Sometimes, people have preferences that are clear and do not change over time. In such cases, argumentation and framing will probably have relatively little effect. However, in other situations, people do not have complete preferences over outcomes. For example, they might have conflicting values, like the tradeoff between the cheapest, the most convenient, and the bestquality option, making an overall valuation impossible. Their preferences may also be different over time, even very short intervals. One set of findings from psychology is that preferences "are frequently constructed in the moment and are susceptible to fleeting situational factors." 30 The extent to which preferences in general are stable and complete is an area of ongoing research, but in any particular situation, the less clearly formed and immutable preferences are, the more likely it is that argumentation has a causal effect on action.

\section{Reason-based Choice}

What is the nature of this causal effect if it is not changing actors' preferences from $x>y$ to $y>x$ ? A prominent alternative to a value-based model of action (like expected utility theory or prospect theory) is reason-based choice. ${ }^{31}$ A value-based model specifies how much an actor values the alternatives along a single dimension, like utility. This type of model explains a choice with reference to its having the highest value. ${ }^{32}$ By contrast, a reason-based choice analysis identifies a variety of reasons for and against the various alternatives and explains a choice with reference to the balance of those reasons. People choose an alternative because they can provide "a compelling argument for choice that can be used to justify the decision to oneself as well as to others." 33

Reason-based choice accords far more strongly with our intuitive ideas about how we reason and make choices. When we normally think and talk about making choices, we consider and present reasons that an option would be better as well as reasons that an option would be worse. This idea is prominent in the international law literature as well as being present in IR. ${ }^{34}$ The fact that individuals can be conflicted in decision making is more consistent with conflicting reasons being hard to reconcile than it is with actors having clear ideas about their ordering of the options.

Many empirically established violations of features of rationality can be easily accommodated in a reason-based framework. One such feature is procedure

29. Slovic 1995, 369.

30. Ariely and Norton 2008, 13. For accounts of psychological research in IR, see Goldgeier and Tetlock 2001; and Shannon and Kowert 2011.

31. See McDermott 2001, 18-26; and Shafir, Simonson, and Tversky 1993.

32. An emerging trend in cognitive science is toward "comparison-only" findings where the brain does not calculate value at all. For a review, see Vlaev et al. 2011.

33. Tversky, Sattath, and Slovic 1988, 372.

34. See Johnstone 2003 for the role "justificatory discourses" play in international law. 
invariance, or the idea that preferences over options are independent of the method used to elicit them. Shafir and colleages point out that notable features provide compelling reasons for the decision: "reasons for choosing are more compelling when we choose than when we reject, and reasons for rejecting matter more when we reject than when we choose." 35

Other violations of rationality that can be accommodated in a reason-based choice framework are the sunk-cost fallacy, preference inversion, framing effects, loss aversion, the endowment effect, status-quo bias, attribute balance, feature creep, and the disjunction effect, among others. ${ }^{36}$ The importance of reasons for decision making is increased when the decision maker has to justify a decision to others. ${ }^{37}$ Such situations are rife in international politics. The inability of standard rational choice theory to account for the role of reasons in decision making has prompted attempts at formalizing preference formation and change in terms of the basket of reasons that are motivationally salient. ${ }^{38}$

A reason-based choice model of action can provide a way for rhetorical argumentation to be causally relevant with respect to choice of action. If actors do not have complete, stable preferences over the options presented, an argument can "highlight different aspects of the options and bring forth different reasons and considerations that influence decision." 39 In choice situations where either preferences are nonexistent or inchoate, or no option dominates (i.e., each option is highest on at least one attribute), an argument could provide a hitherto nonsalient reason for or against an option.

This shows that it is not necessary for anyone to change their mind for rhetorical arguments to have a causal effect on action. Actors can engage in strategic rhetorical action while also being involuntarily susceptible to the sometimes-subconscious effects of argumentation. One type of effect can be to change the normative status of an action or situation.

Rhetorical action matters more when there is a third-party audience who is undecided or whose conception of a situation's meaning is not fixed, or whose support is up for grabs in some way. Krebs and Jackson have elaborated a general model of rhetorical action that incorporates the role of this audience. ${ }^{40}$ In this model, two actors are arguing over a policy and a third actor, the audience, is crucial to the success of this policy. The two arguers (the claimant and the opposition) engage in rhetorical contestation to win over the audience. Whichever actor is more successful in this rhetorical contestation is rewarded with more or less support or resistance for the policy in question. Rhetorical coercion occurs when one actor is forced to stop arguing against or even to advocate for a policy. Rhetorical coercion is possible because actors need to

35. Shafir, Simonson, and Tversky 1993, 18.

36. For a review, see Mercier and Sperber 2011, 70-71.

37. Simonson 1989.

38. See Dietrich and List 2011, 2013.

39. Shafir, Simonson, and Tversky 1993, 34.

40. Krebs and Jackson 2007. 
justify their behavior to each other and because these justifications are constrained (e.g., by the limits of intersubjectively shared discourse).

Say there is a policy $p$ that has a set of reasons in favor and also a set of reasons against or objections $o_{1}, o_{2}, \ldots, o_{n}$, such that the audience does not have a clear stable preference over whether the policy is enacted or not. If the audience finds a potential objection $o_{i}$ compelling in some way, the audience resists the action. ${ }^{41}$ Argumentation can be used to remove an objection by altering the normative status of the policy. A common way to remove an objection is by changing the normative status from a clear violation of a norm to an excused exception to the norm. The argument is then causally relevant to the action in the case that the action would not have occurred in the face of resistance by the audience, ceteris paribus. Here, removing an objection does not mean that policies of the same type as $p$ are forever believed to be morally right by everyone. All that it means is that resistance to policy $p$ is reduced or eliminated in this particular case. This conception of the effect of argumentation allows that an argument can be successful at removing an objection and yet have no impact on behavior because the balance of reasons is still heavily one sided. The recognition of Bangladesh is an especially good case to observe the effect of argumentation on behavior because the reasons for and against were relatively evenly balanced.

As Kornprobst notes, there can be different levels of support for, or a lack of resistance to, a policy. He identifies acquiescence, compromise, and consensus. ${ }^{42}$ Acquiescence is the weakest; people simply acquiesce with a dominant argument but they are not convinced. Compromise involves people who are not convinced but actively agree to mutual concessions as long as they do not violate their deepest-held beliefs. Consensus, the strongest, is when actors both publicly agree with and internally believe in the policy. These are differing levels of support for a policy. Resistance to a policy similarly varies. People could simply refuse to support the policy, effectively doing nothing. They could grudgingly adopt the policy while still challenging its justification. They might both reject the policy and argue against it. At the extreme, they could reject the policy and actively take steps to try and reverse it. When a policy's success is dependent upon the attitudes and actions of an audience group of states, altering the level of support or resistance to that policy is an important goal of both the claimant and opposition groups. ${ }^{43}$

\section{What Makes For a Better Argument?}

If argumentation can have these effects, what is it that determines which arguments are successful and which fail? For Krebs and Jackson, as in many accounts of

41. See what follows for a discussion of differing levels of resistance to action.

42. Kornprobst 2014, 197.

43. In the same way that inquiring into the genesis of actor preferences is a separate endeavor in rationalist analyses, the source of an audience's "willingness to accept" is a separate research task from analyzing effects on argumentation and behavior. 
rhetorical action (and framing and securitization), ${ }^{44}$ the public's or audience's acceptance or rejection of the framing or implications of a claimant's arguments are central. The audience serves as the adjudicator of the better argument. ${ }^{45}$ Krebs and Jackson largely bracket the question of why a public finds an argument acceptable. But it seems reasonable that there are multiple influences on a public's acceptance or rejection of an argument. One of these influences, they posit, is the limits on creating or formulating the basic building blocks of argumentation-rhetorical commonplaces; "they are not free to deploy utterly alien formulations in the course of contestation; such arguments would fall ... on deaf ears." 46 This is not the only conceivable limitation. Some writers have looked to features of the normative ideas themselves, ${ }^{47}$ or to a comparison with some sort of ideal to try and explain why audiences find some arguments more acceptable than others. For example, Elster posits that the appearance of impartiality and consistency is a crucial factor, going so far as to appeal to a "civilizing force of hypocrisy." 48

A seemingly obvious factor is the role of evidence. My argument relies upon the idea that empirical evidence supporting an argument makes that argument more convincing. This seems uncontroversial ${ }^{49}$ and is the foundation of the rationalist literature on communication. For rationalists, effective communication takes the form of costly signaling ${ }^{50}$ or cheap talk ${ }^{51}$ and is evaluated on those terms. However, even though these are important and useful ideas, they are at best incomplete. Even costly signals require interpretation. For example, whether a costly signal can change beliefs requires that "there is objective and uncontestable knowledge, shared among sender and receiver, about what costs mean to either."52 Jervis makes the point that "actions are not automatically less ambiguous than words. Indeed, without an accompanying message, it may be impossible for the perceiving actor to determine what image the other is trying to project."53

With many political phenomena, communication is complicated by the ubiquity of essentially contested concepts. An issue with some existing work is the stark distinction usually drawn between "signaling facts" and "entering a moral discourse." 54 While it is reasonable to draw this distinction in the abstract, people in practice often experience moral discourse as an indistinguishable part of empirical discourse. In particular, people often see moral judgments as resting definitively on empirical

44. Watson 2012, 284-85.

45. See also Ulbert and Risse 2005, 353.

46. Krebs and Jackson 2007, 45.

47. For example, Risse, Ropp, and Sikkink 1999 suggest that norms dealing with physical injury are more appealing than other types of norms.

48. Elster 1998, 111.

49. Nyhan and Reifler 2010 would disagree because they find that, for the politically engaged, evidence correcting a misperception actually increases the misperception rather than overturning it.

50. See, for example, Fearon 1997 and Schelling 1960.

51. For example, Sartori 2005.

52. Müller 2004, 398.

53. Jervis 1970, 19.

54. For example, Müller 2004, 400. 
facts. However, despite their importance to decision making, it is not clear what the empirical referent of concepts like democracy, corruption, genocide, terrorism, or aggression are. ${ }^{55}$ Further, social norms, rules, and institutions have an "open texture" in the sense that they refer to classes of persons and classes of acts, things, and circumstances and as such it is uncertain whether and how they apply "in particular concrete cases." 56 To come to a judgment on whether an action or actor has a property, like that of being democratic, or being genocide, or being the product of self-determination, people use shorthand indicators. As Hanrieder points out, ${ }^{57}$ morally complex situations are resolved through the performance of "critical tests" which rely on some performance, including actions or reference to symbols.

Boltanski and Thevenot note that normative reasoning does not often take the ideal form represented in philosophy journals in which reasoning over the empirical situation and the normative situation are kept strictly separate. Instead, in practice people resolve contests over normative concepts (like the legitimacy of an action or whether an act or a situation is an instance of a norm) by pointing to particular empirical facts as determinative of normative conclusions. In conditions of ambiguity and uncertainty, such as a contestation over legitimacy, people rely on "reality tests" 58 in which judgments about the fluid and plastic social world rest on "the factual nature of the elements that have been invoked." 59 For example, when reacting to a police officer's killing of a suspect, people might rest their moral judgment solely on whether the suspect was armed or unarmed, or who shot first, despite this only being one small part of the possible complex normative argumentation we could build around this question.

Similarly, Mor mentions how important the "provision of some new facts (selected and presented with a certain interpretation in mind)" is for the process of legitimation and counter-legitimation that affects external support for an actor's position. ${ }^{60}$ In the framing literature, "empirical credibility" 61 is a constraint on framing events. The issue is not whether "claims are factual or valid, but whether their empirical referents lend themselves to being perceived as "real' indicators of the diagnostic claims." 62

So, a normative argument can be better if it makes a normative label more convincing through referring to some fact about the situation. But what facts are relevant or

55. We could go further and say that there is no truth of the matter, except in terms of what humans do in practice treat as instances of these concepts. Searle 2010.

56. Hart 1994, 123-24.

57. Hanrieder 2011, 409.

58. Boltanski and Thevenot 1999, 367.

59. Boltanski and Thevenot 2006, 133. The word facts here refers to claims about the world that are relatively objective, such as existential claims about physical objects, as opposed to interpretations of those facts. For example, the concept of permission is crucial to whether some action is treated as theft, trespassing, a violation of sovereignty, sexual assault, and so on. Whether someone is judged to have permission often depends on reference to a particular empirical fact, like whether a piece of paper has been signed or whether a sign was displayed.

60. Mor 2012, 407.

61. Benford and Snow 2000, 620. See also Snow et al. 1986.

62. Benford 2011, 72. 
influential? Actors are not able to say anything they like and have an audience accept their formulation. If there are rules governing the type of situation, those rules specify relevant facts. But even when rules are precise and comprehensive, there is inevitably a judgment made on whether a particular case counts as an instance of the general categories referred to in the rules. Those judgments are made with reference to an intersubjectively defined collection of characteristics. What matters is not the truth of the matter but the socially defined markers of what counts. This idea is related to the concept of a "practice" or a competent performance of a socially recognized pattern of behavior, ${ }^{63}$ and is linked to the theme in the argumentation literature that arguments have to be anchored in something that is widely taken for granted, or rhetorical commonplaces, for them to make sense and be convincing. ${ }^{64}$ One example comes from the procedure for obtaining US resident alien status via spousal application (a "green card"). A vital element is whether the relationship between the petitioner and spouse conforms to the practice of a "bona fide marriage" according to the United States Citizenship and Immigration Services, including whether there are any "discrepancies in statements on questions for which a husband and wife should have common knowledge." ${ }^{65}$ A competent performance of a "bona fide marriage" here relies upon conforming to a set of socially defined or intersubjective characteristics.

To summarize, unlike rationalist or persuasionist claims, arguments can have effects by providing reasons for or against a policy, especially when the support of a third-party audience is up for grabs. These effects include changing the normative status of an action, such as from a norm violation to an excused exception. Normative arguments can be made more convincing when they are anchored in empirical evidence, such as the actions of the parties, but this evidence is effective only when it is rhetorically linked to the argument. If an action conforms to some intersubjectively defined criteria, that is, is a competent performance, it is more likely to be accepted. These ideas together suggest a mechanism whereby actors can use actions to bolster normative arguments. I call this mechanism "rhetorical adduction."

\section{Rhetorical Adduction}

Rhetorical adduction is the process by which states try to raise support for their position first by constructing an argument in which a particular action represents part of an argument, and then by performing that action to make the argument seem more convincing. Here I lay out a schematic account of the process. See Figure 1 for a representation of the process.

63. Adler and Pouliot 2011, 3.

64. See Crawford 2002; and Krebs and Jackson 2007.

65. "Adjudicator's Field Manual," chapter 21.3, section (a), paragraph (2), subparagraph (h), United States Citizenship and Immigration Services, <http://www.uscis.gov/iframe/ilink/docView/AFM/HTML/ AFM/0-0-0-1.html>, accessed 6 September 2016. 


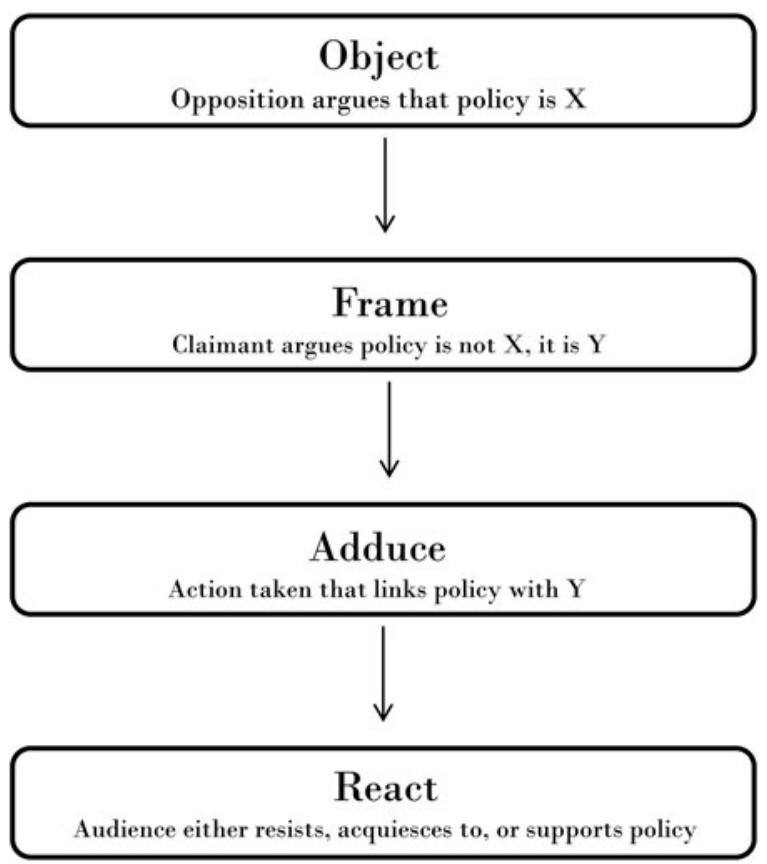

FIGURE 1. The Process of Rhetorical Adduction

Two groups of states have a dispute over a policy whose success depends in some way on the actions of a third group of states uncommitted or undecided about the policy. For simplicity, the policy could take one of two values; it could either be enacted or not. The group of states that wants the policy enacted is denoted $\mathrm{C}$, the claimant. The group of states that does not want the policy enacted is denoted $\mathrm{O}$, the opposition. The undecided group of states is denoted $\mathrm{P}$, the public or audience, which can either resist or support the policy (or at least acquiesce in its enactment). $\mathrm{O}$ makes an argument. This argument raises an objection to the policy that involves a claim that the policy is illegitimate because it has property $\mathrm{X}$. $\mathrm{C}$ then makes a counterargument, in which $\mathrm{C}$ claims that the policy does not have property $\mathrm{X}$ and that instead the policy has property $\mathrm{Y}$, which means that it is not illegitimate. Further, the counter-argument specifies some action, A, that demonstrates that the policy has property Y. C then performs action A. P then supports the policy.

What does rhetorical adduction consist of in this process? First, it involves the counter-argument that the policy has a property that means it is legitimate, including the claim that a particular action means the policy has that property (the rhetorical part). The second part of rhetorical adduction is actually performing that action as "proof" that the policy has the property (the "adduction" part).

At several points in this process, it may get derailed. O may not, or may not be able to, make an argument. C may not, or may not be able to, concoct a counter-argument 
that makes sense. C may then not be able to perform the action. Even if it is performed, it may not be convincing to the audience, which may then decide not to support the policy.

An ideal type of the underlying structure of the argumentation involved in rhetorical adduction is the following: 66

1) Policy $p$ has property $\mathrm{X}$.

2) If a policy has property $X$, it is illegitimate.

$2 *)$ Thus, $p$ is illegitimate.

The argument being made by $\mathrm{O}$, the opposition to the policy at stake, is that because policy $p$ has property $\mathrm{X}$, it is illegitimate $(1,2, \rightarrow 2 *)$.

3) A policy cannot have both property $X$ and property $Y$.

4) Policy $p$ has property Y.

5) Thus, policy $p$ does not have property $X$.

$\left.5^{*}\right)$ Thus, policy $p$ does not have property $\mathrm{Y}$.

6) Thus, $2 *$ is false.

The counter-argument being made by the claimant $\mathrm{C}$ is that the policy has property $\mathrm{Y}$ and that, because a policy cannot have both $\mathrm{X}$ and $\mathrm{Y}$, the policy does not have $\mathrm{X}$ and thus is not illegitimate $(3,4, \rightarrow 5, \rightarrow 6)$. Crucially, the audience has to resolve the contradiction between 1,3 , and 4 in favor of conclusion 5 rather than $5 *$. Part of rhetorical adduction is making it so that 4 is more plausible than $1(7,8, \rightarrow 4)$.

7) If $Z$, then policy $p$ has property $Y$

8) Z.

Here $\mathrm{Z}$ is some fact with an empirical referent, such as an action. For intuitiveness, an everyday example might be a situation in which a faction in a university department wants to hire an inside candidate, but they are opposed by another department faction, on the basis that this would be illegitimate. Possible arguments might be that this would be nepotism, or that the person might not be the best candidate. The first faction then argues that if they run a standard search, the result of that search would not be nepotism and would be the best of available candidates, and hence be legitimate. The department runs the search, and then selects the inside candidate. The central administration then acquiesces to this decision.

66. Despite this ideal-typical representation, in practice people often do not conform to formal logical rules. Toulmin 2003 identifies parts of argument that people do in fact use and defines warrants or inference-licenses that authorize a move from data to claim, and backing, which serves to support or justify the warrants. Rhetorical adduction includes the provision of warrants in that it involves linking some proposed data with a claim about the policy at issue, and the provision of backing for those warrants through performing an action that supports the warrant. 


\section{Applying the Model: Indian Intervention in Pakistan and the Recognition of Bangladesh}

To demonstrate how the rhetorical adduction model explains behavior, I apply the model to the peace-making process at the end of the Indo-Pakistani war of 1971. In particular, the model can explain both why India withdrew its troops from East Pakistan/Bangladesh so quickly after defeating West Pakistani forces, and why states that initially opposed India's actions and the creation of a new state ended up recognizing Bangladesh.

The recognition of the new state of Bangladesh was made possible by rhetorical adduction. That is, an argument was made that the proposed withdrawal of Indian troops from Bangladesh meant that recognizing Bangladesh would not violate norms of non-aggression, self-determination, or the international legal norm of effective control of territory. Indian troops were withdrawn from Bangladesh to bolster these arguments. Some states recognized Bangladesh because the Indian agreement to withdraw and then actual withdrawal of troops removed their objections to recognition. By contrast, states were not predisposed to recognize Bangladesh because of the mass killing of Bengalis, nor were they simply applying the international law of sovereignty to the situation. India did not withdraw troops because they experienced or anticipated high occupation costs.

\section{Historical Context}

Three themes in the historical context were relevant to the arguments over recognition. ${ }^{67}$ First, was the putative Bangladeshi state a result of self-determination? Second, what was the attitude of the international community to India's use of force? And third, what was the attitude of decision makers in other states toward a potential new state of Bangladesh?

The feature most relevant to the question of self-determination for Bangladesh was the democratic election held in Pakistan in December 1970, its first since independence from Britain and partition from India in 1947. Sheikh Mujibur Rahman's Bengali nationalist party, the Awami League, won an overall majority of seats in the parliament (including both East and West Pakistan). However, the league was prevented from forming a Pakistani government by Zulfikar Ali Bhutto, leader of the Pakistan People's Party, which had won a majority of the seats from West Pakistan, and the previous leader, President General Yahya Khan. Starting in March 1971, a violent crackdown on Bengali political opposition by West Pakistani armed forces left hundreds of thousands dead ${ }^{68}$ and included the incarceration of Sheikh Mujib. This resulted in a massive outpouring of refugees across the 
border into Indian Bengal. In April, the Awami League issued a declaration of independence that was initially ignored internationally.

India's intervention into East Pakistan was widely criticized. Soon after the violence began, the number of refugees fleeing to India was estimated to be in the millions and Prime Minister Indira Gandhi decided on a military intervention into East Pakistan. ${ }^{69}$ In October, the Indian army began launching attacks and holding territory inside East Pakistan..$^{70}$ India declared war on Pakistan on 3 December, citing selfdefense against Pakistani air attacks. However, India was widely treated as the initiator of cross-border violence. Bhutto, the new president of West Pakistan, argued that a USSR-proposed Security Council resolution transferring sovereignty to Bangladesh meant legitimizing aggression:

This is gunboat diplomacy in its worst form. It makes the Hitlerite aggression pale into insignificance, because Hitlerite aggression was not accepted by the world. $^{71}$

Impose any decision, have a treaty worse than the Treaty of Versailles, legalize aggression, legalize occupation, legalize everything that has been illegal up to 15 December 1971. I will not be a party to it. ${ }^{72}$

Similar sentiments were expressed by some other states and the resolution was not adopted. Other UNSC resolutions that merely called for a ceasefire and a withdrawal to internationally recognized borders but that pointedly excluded the transferal of political authority to the Awami League and Bangladesh were vetoed by the USSR. This stalemate in the Security Council led to the transfer of the issue to the General Assembly and subsequently the near-unanimous (104 to 11 with ten abstentions) General Assembly resolution 2793, which duplicated the resolutions vetoed by the USSR. Indian military success continued as the USSR vetoed another UNSC resolution on 13 December and the next day, Pakistani forces in East Pakistan proposed a ceasefire, which India accepted. However, after the end of hostilities, India's victory was not immediately accepted and normalized by those states who had been so vociferously denouncing the invasion only days before. As Henry Kissinger said to US President Richard Nixon, "the Indians are demanding the UN agree for the turnover

69. Kux 1994, 290.

70. Sisson and Rose 1990, 213.

71. United Nations Security Council Official Records, S/PV.1614, 14-15 December 1971, 74. Available at $<$ http://dag.un.org/handle/11176/143123>.

72. Ibid., 84. Bhutto made this same argument in private, bilateral exchanges, for example, with UK Prime Minister Edward Heath: "this will be the first instance of Britain accepting and endorsing the dismemberment of a Commonwealth country achieved through aggression ... The intended recognition of 'Bangladesh' by Britain would ... put a seal of respectability to an aggression against a Commonwealth country and set a dangerous precedent for the future." Letter from Bhutto to Heath, 19 January 1972, UK National Archives, Premier's Archives, PREM 15/751, "Visit of Sheikh Mujib, Prime Minister of Bangladesh, to London: UK recognition of Bangladesh," 3 January-4 February 1972 (henceforth cited as PREM 15/751). 
of authority to the Bangla Desh. Now that would make the UN an active participant in aggression. I don't think we can agree to this." 73

Before and during the war between India and Pakistan, no states had a clear preference for the existence of a new Bangla Desh state (apart from the belligerents). Based on Indian governmental and personal papers, Bass recounts the efforts of Gandhi, P.N. Haksar, principal secretary to the president, and Indian diplomats in a global appeal for help. Initially appealing to sixty-one countries, the Indians tried to publicize what they called the genocide against the Bengalis. External Affairs Minister Swaran Singh personally visited numerous foreign capitals in June 1971, Education Minister Siddhartha Shankar Ray toured Asia, and Home Affairs Minister K.C. Pant traveled around Latin America, all asking for help with the refugee problem and specifically asking for recognition of Bangla Desh. No states agreed to recognize, and only a few made public statements of sympathy or support. Bass describes the whole enterprise as "crushingly disappointing." 74 Even the Soviet Union, publicly supportive of both India and Bangladesh throughout the crisis, resisted. Alexei Kosygin, Soviet premier, privately urged D.P. Dhar, Indian Ambassador to Moscow, to avoid war with Pakistan, and subsequently told Singh not to recognize Bangladesh. ${ }^{75}$ What this indicates is that most states were against recognition before the war, or at the very least were unclear about whether they wanted to recognize Bangladesh. In a memorable episode, Mexico's president had so little idea about the situation that he refused to believe that West and East Pakistan were so far apart until an atlas was fetched, at which point he said, "By God, it's really so."76

Apart from India and Bhutan, no states recognized Bangladesh before 11 January 1972, even after the end of hostilities on 14 December. Between 11 January and 14 February 1972, thirty-six states recognized Bangladesh, including the UK and nine others on 4 February (see Figure 2). The US did not recognize Bangladesh until 4 April. Bangladesh applied for UN membership later that year, but a UNSC resolution admitting the new state was vetoed by China in August. Bangladesh was not admitted to the UN until 1974.

\section{The Role of Troop Withdrawal}

After Sheikh Mujib was released from captivity in West Pakistan, he traveled to London where, in a meeting on 8 January 1972, the British government impressed

73. Transcript of telephone conversation between President Nixon and the president's assistant for National Security Affairs (Kissinger), 15 December 1971, Foreign Relations of the United States 19691976 (henceforth cited as Foreign Relations of the US), vol. 11, 315. Available at <https:/history.state. gov/historicaldocuments/frus1969-76v11/d315>.

74. Bass 2013, 136-41.

75. Ibid., 136, 138.

76. Ibid., 139. 


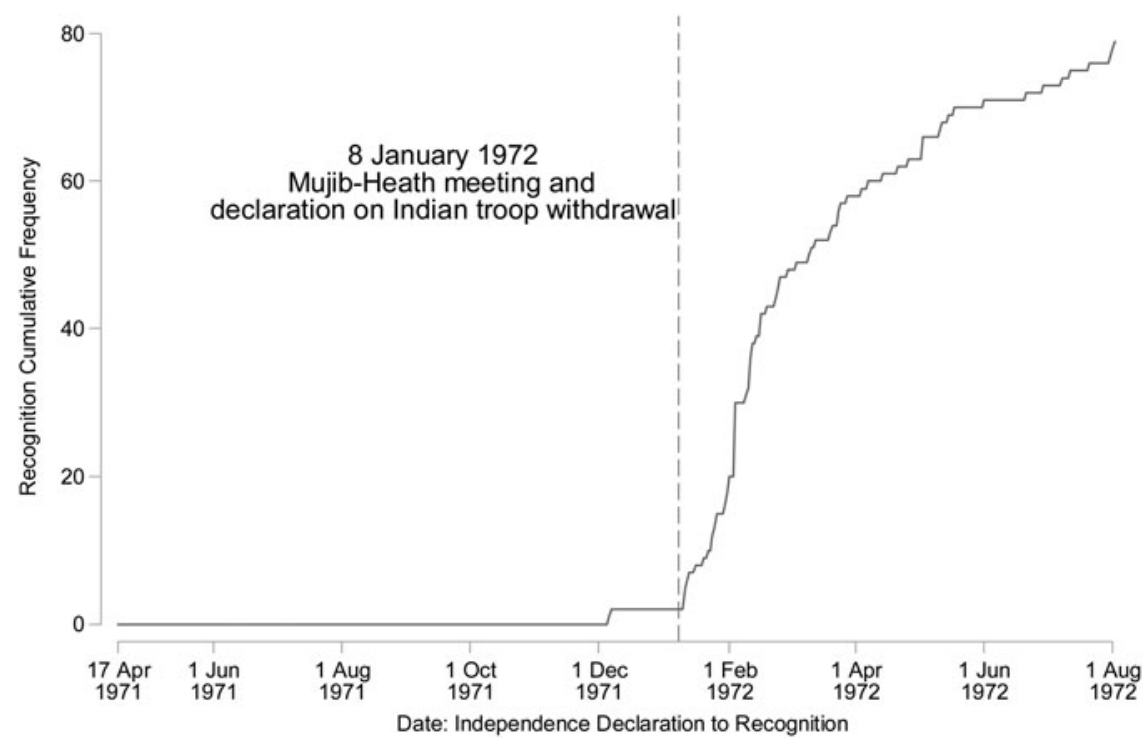

FIGURE 2. Timing and Recognition of Bangladesh

upon him the importance of Indian troop withdrawal for the recognition of Bangladesh. ${ }^{77}$ However, the connection between these two things was not immediately apparent. For example, UK Ambassador to Turkey Roderick Sarell reported that the senior members of the Turkish foreign policy establishment had agreed to not recognize Bangladesh only after the Indian troop presence in Bangladesh was presented to them as an issue and a barrier to recognition. ${ }^{78}$ Similarly, the Sri Lankan (Ceylonese) government asked "whether Mujib has stated publicly that Mrs Gandhi has agreed to withdraw Indian forces on his request," but only after having it explained to them that withdrawal was relevant to recognition. ${ }^{79}$ Mujib and members of the Indian government insisted that Indian troops were in Bangladesh only at the request of the Bangladeshi administration and Gandhi and Mujib jointly declared on 8 February 1972 that India would withdraw all its troops from Bangladesh by 25 March. ${ }^{80}$ Mujib in fact declared that all troops were withdrawn on 13 March. 81

77. Notes on Heath-Mujib Meeting, 8 January 1972, PREM 15/751.

78. Cable from Sarell, 25 January 1972, UK National Archives, Foreign and Commonwealth Offices, FCO 37/1020.

79. Cable from Mackintosh, 25 January 1972, FCO 37/1020.

80. "Firm Stand Taken by Mujib in Talks: Bangladesh Shows Desire to Cut Loose From India," New York Times, 9 February 1972, 9.

81. "India's Soldiers Quit Bangladesh: Ceremonies in Dacca Mark Pullout After Three Months," New York Times, 13 March 1972, 7. 
There were three arguments to which Indian troop withdrawal was crucially linked. First, withdrawal meant that the Indian military intervention did not count as aggression, or was an excused exception to the general rule, so recognizing the fruits of that intervention did not count as legitimizing aggression. This might sound counterintuitive; an aggression is not undone if the perpetrator withdraws afterwards. ${ }^{82}$ However, the case was made that a key characteristic of aggression or a war of conquest was the desire to annex or occupy territory, and withdrawal indicated that India had no desire to do so. So the invasion was in effect recast as an excused exception to the rule against the use of force. Analogously, whether taking an object counts as theft or borrowing depends on whether it is given back. Second, withdrawal was also claimed to mean that the creation of the state of Bangladesh was an act of self-determination. Third, and finally, the conventional international legal criteria for recognition included effective control of territory and so recognition was not impeded by being illegal. There was no question that Indian troops had crossed the border into East Pakistan. The issue to be resolved was whether this counted as aggression, or whether the presence of Indian troops meant that the nascent Bangladesh government did not enjoy popular support.

In terms of the rhetorical adduction model (see Figure 3), the policy at stake is the recognition of Bangladesh. The claimant is the Mujib administration, India, and other states like the UK who want Bangladesh to be recognized. The opposition includes Bhutto and the West Pakistan leadership, as well as China. The opposition charges that recognition is illegitimate because it has the following properties: (a) it would mean approving of aggression; (b) the Mujib government does not enjoy popular support; and (c) the Mujib government does not and cannot control the territory of East Pakistan. The claimant counter-argument is that if India withdraws its troops, then recognition will no longer imply approval of aggression and the Mujib government can be said to both enjoy popular support and control its territory.

Note that I do not provide a complete account of the decisions to recognize Bangladesh, which were multifaceted. ${ }^{83}$ The relevant claim here is that there were potential objections or sources of resistance to the recognition policy that were removed by rhetorical adduction. In the Bangladesh case, the sole remaining objections were removed and so rhetorical adduction made the difference between policy adoption and non-adoption. Two counterfactual scenarios are the following:

Counterfactual: What if the UK, India, and others had not argued that withdrawal excused the Indian invasion and legitimated the Bangladesh state?

If the UK and others had not fixed upon Indian withdrawal of troops as an indicator of the legitimacy of the use of force by India, and of the Mujib regime, then there would

82. I thank an anonymous reviewer for raising this point.

83. That would be the goal of explaining outcomes' process tracing. See Beach and Pedersen 2013. 


\section{Object}

Pakistan et al. argue that recognition is legalizing aggression, that Mujib administration does not have popular support and does not have territorial control

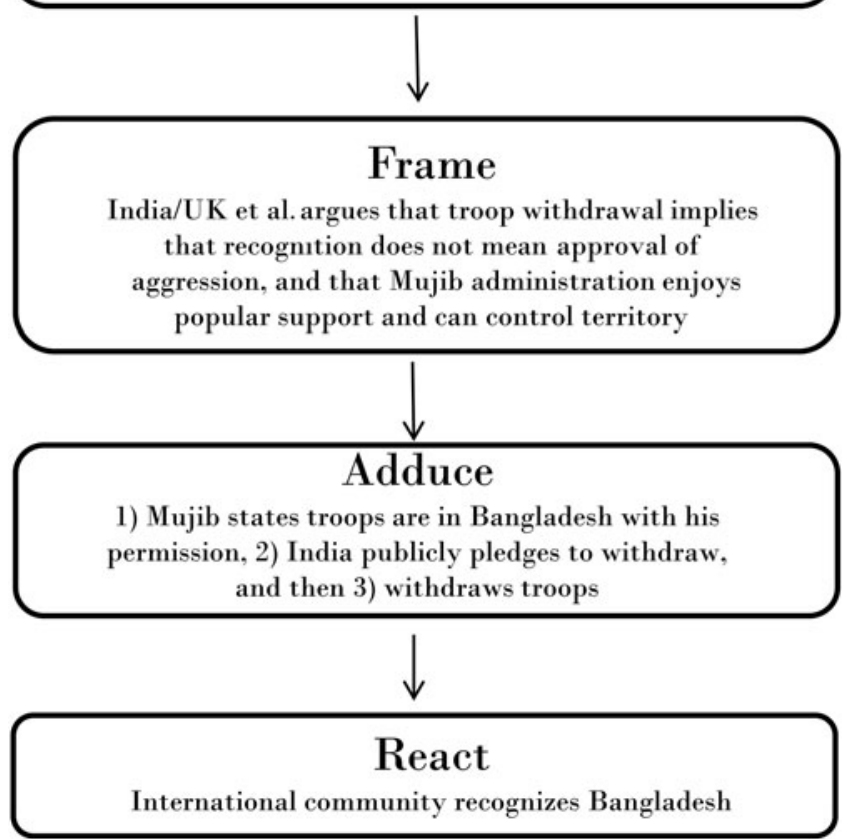

FIGURE 3. Rhetorical Adduction and Recognizing Bangladesh

have been no reason for India to withdraw troops. Prior discussions between India and Bangladesh involved an Indian military presence.

\section{Counterfactual: What if India had not withdrawn troops?}

In a counterfactual world where India did not withdraw troops, resistance to the recognition policy would have been higher and some states would not have recognized Bangladesh.

\section{Observable Implications}

The policy of recognizing Bangladesh was made possible by a combination of creative argumentation and the action of withdrawing Indian troops. So recognition happened (at least for some states) because of the argumentation and withdrawal. Also, 
withdrawal happened because of India's and Bangladesh's desire to legitimate recognition. What are the observable implications of these claims, given the theory I outlined? First, we should see explicit linking of the action (i.e., withdrawal) with the policy (i.e., recognition). Actors might say something like, "We have to do this (the action) so that the others can/will do that (the policy)," or "We have done this (the action), so now you can/must do that (the policy)." Second, we should see the recognition decision happen after the action that was adduced. Third, we should see explicit conditioning of the recognition decision on the action.

\section{Claimant Linking Action to Policy}

After Mujib's meeting with Heath in London on 8 January, members of the UK government accepted that Indian troops were in Bangladesh with the agreement of the Bangladeshi government, and that they would be withdrawn. From this meeting onward the British, the Indians, and the Mujib administration argued that the prospective withdrawal of Indian troops meant that recognition of Bangladesh was now an acceptable policy.

By 18 January 1972, British diplomats were arguing to other governments that recognition could go ahead because "it seemed to us that the normal criteria for recognition were just about fulfilled and we did not regard the presence of Indian troops, particularly given what had been said in public by Sheikh Mujib about their status and their eventual withdrawal, as a serious obstacle." ${ }^{84}$ In personal messages to state leaders, Heath argued that:

whatever view is taken of the manner of its creation, a new national entity is coming into being whose Government appears to command the general acceptance of the majority of the people. The maintenance of law and order is still, in the last resort, dependent upon the Indian Army, but their presence is accepted by the Government in Dacca and Mujib told me that, on his return, he would formally request the Army's withdrawal in accordance with a phased and agreed plan. ${ }^{85}$

The reference to the manner of Bangladesh's creation can only refer to the illegitimacy of India's use of force. In parliament sessions, at Foreign Ministry press conferences, and during the prime minister's question time throughout January and February, the standard answers provided to questions about the presence of Indian troops, or the status of Bangladesh, were that Indian troops were in Bangladesh "by the will" 86 of the government, or "at the request" 87 of Mujib. 
TABLE 1. Observable Implications

\begin{tabular}{ll}
\hline Category of Evidence & Summary of Evidence \\
\hline $\begin{array}{c}\text { Claimant linking action to } \\
\text { policy }\end{array}$ & $\begin{array}{c}\text { The UK as well as India and Bangladesh actively made the case to other states that } \\
\text { Indian troop withdrawal would mean that recognition of Bangladesh was accept- } \\
\text { able and legitimate and in accordance with international norms }\end{array}$ \\
$\begin{array}{c}\text { Conditioning of policy decision } \\
\text { on action } \\
\text { Action before policy } \\
\text { troops had been withdrawn or until India committed publicly to withdraw }\end{array}$ \\
$\begin{array}{c}\text { No states, other than India and Bhutan, recognized Bangladesh until Mujib publicly } \\
\text { stated that Indian troops were in the country at his request and that he would ask } \\
\text { them to leave }\end{array}$ \\
\hline
\end{tabular}

\section{Conditioning of Policy Decision on Action}

Prior to the Mujib-Heath meeting on 8 January 1972, only two states, India and Bhutan, had recognized the state of Bangladesh, and no states had done so since the end of the fighting and the ceasefire declaration on 17 December $1971 .^{88}$ There were four categories of reasons given to British officials for why recognition of Bangladesh might be a problem. ${ }^{89}$ One was that recognition might negatively affect the state's relations with Pakistan, and for some states, like Portugal and Hungary, this was their only stated concern. However, many states conditioned their recognition decision on an action related to Indian troop withdrawal and gave three different types of reasons for doing so. States also differed in the extent of troop withdrawal they required before recognition. See Table 2 for a full list of states, their stated reason for conditioning recognition on withdrawal (if any can be identified), and what recognition was conditioned on (whether actual withdrawal or a proxy).

The first type of reason, opposition to condoning or legitimizing aggression, is labeled as "Non-aggression." A good example comes from Mexican Foreign Minister Emilio Óscar Rabasa who reported that the Mexican president had decided not to recognize Bangladesh because, "since the Mexicans, like many Latin Americans, refuse to condone territorial aggrandizement as a result of war, they would prefer to wait on the withdrawal of Indian troops as the sign of true independence. $" 90$

This statement also appeals to "true independence." Self-determination is another important value expressed by the Mexican representative and is the second type of reason commonly appealed to as justifying recognition as Bangladesh. For

88. See Figure 2.

89. A frequent concern was that states had to recognize in a group, or on the same day as multiple other states. However, even allowing for minor coordination problems, this in and of itself cannot explain the length of time taken to make recognition decisions and declarations.

90. Cable from Hope, 16 January 1972, FCO 37/1020. 
example, Australia's justification of its decision to recognize Bangladesh includes that "there was no doubt of the breadth and depth of the support which Sheikh Mujib's Government enjoyed among the people of Bangla Desh." 91

TABLE 2. Conditioning Recognition on Indian Troop Withdrawal

\begin{tabular}{|c|c|c|c|}
\hline State & Stated reason $(s)$ & Stated condition & Reference \\
\hline Argentina & Other & Withdrawal & FCO $37 / 1020$ \\
\hline Australia & Control of territory, Self-determination & Statement & PREM $15 / 751$; FCO $37 / 1023$ \\
\hline Belgium & Non-aggression & - & S/PV. 1607: 222 \\
\hline Burundi & Non-aggression & - & S/PV. 1621: 56 \\
\hline Canada & Control of territory & Statement & FCO $37 / 1020$ \\
\hline Ceylon / Sri Lanka & Non-aggression & Statement & FCO 37/1020; FCO 37/1023 \\
\hline China & Non-aggression & Withdrawal & FRUS 69-76 XI: 274 \\
\hline Cyprus & Control of territory, Self-determination & Agreement & FCO $37 / 1020$ \\
\hline France & Control of territory & Agreement & FCO $37 / 1019$ \\
\hline Indonesia & Non-aggression, Control of territory & Statement & FCO 37/1020; FCO 37/1025 \\
\hline Ireland & - & - & FCO $37 / 1020$ \\
\hline Italy & - & Statement & FCO $37 / 1023$ \\
\hline Japan & - & - & FCO $37 / 1024$ \\
\hline Malawi & Control of territory, Self-determination & Statement & FCO $37 / 1025$ \\
\hline Malaysia & Non-aggression, Control of territory & Statement & FCO $37 / 1023$ \\
\hline Mexico & Non-aggression, Self-determination & Withdrawal & FCO $37 / 1020$ \\
\hline Nigeria & Other (secessionism) & Withdrawal & FCO $37 / 1024$ \\
\hline Philippines & Other (secessionism) & Withdrawal & FCO $37 / 1023$ \\
\hline Senegal & Control of territory & - & FCO $37 / 1020$ \\
\hline Sierra Leone & - & Withdrawal & FCO $37 / 1025$ \\
\hline Somalia & Non-aggression & - & S/PV. 1606: 240 \\
\hline Syria & - & - & S/PV. 1606: 374 \\
\hline Turkey & Control of territory & Withdrawal & FCO $37 / 1020$ \\
\hline UK & Control of territory, Self-determination & Agreement & FCO 37/1020; PREM 15/751 \\
\hline US & Non-aggression, Other & Withdrawal & FRUS $69-76$ XI:315 \\
\hline USSR & - & Statement & FCO $37 / 902$ \\
\hline
\end{tabular}

Notes: FCO: UK Foreign and Commonwealth Offices Archives; S/PV: United Nations Security Council Official Record; PREM: UK Premiers Archives; FRUS: Foreign Relations of the United States series.

The third type of reason was whether the Mujib administration had control of the territory. This was part of the often-cited international legal criteria and played a central part in several states' reasoning. For example, Mitchell Sharp, Canadian Minister of Foreign Affairs, worried about "the question that is concerning everyone, namely, is the govt that has been formed in Bangladesh really in authority and what is the effect of the presence of Indian troops." 92

States also varied in what exactly they were conditioning their decision on. Many recognition decisions came after actions that were effectively proxies for the withdrawal of Indian troops. While some states required actual verified withdrawal, others were willing to accept reassurances from the Bangladesh and Indian governments. For the UK, Mujib's assurance that Indian troops were in Bangladesh "at 
his behest and [that] the Indian Government has undertaken to withdraw them at his request," was enough. ${ }^{93}$ Ever since Mujib's meeting with UK Prime Minister Heath on 8 January, in which Mujib pledged to request the withdrawal of Indian troops as soon as possible, the UK government had been explicitly linking Mujib's pledge with the recognition of Bangladesh. Previously, UK representatives had focused on the actual presence of Indian troops as a barrier to UK recognition when communicating with other governments, such as Germany ${ }^{94}$ and Vietnam. ${ }^{95}$ This was despite the fact that UK Foreign Minister Alec Douglas-Home had said, "the British interest lies in recognising Bangla Desh sooner rather than later. Once we have recognised, we shall be in a better position to seek to influence the general policies of the new government and to protect British interests in the area." ${ }^{96}$ His reasoning was that it was "wrong to recognise for so long as the supreme authority in the territory of Bangla Desh is in practice exercised by the Indian Army commanders." 97 Once it was clear that "the Indian Army had begun to leave; and those elements which remained did so at the request of [Mujib]," Douglas-Home informed the cabinet that the UK would recognize..$^{98}$ India also repeatedly and publicly stated that its army would leave at the request of Mujib. ${ }^{99}$

Countries like the UK who stated that they were conditioning recognition on Mujib's agreeing that Indian troops were in the country with Mujib's permission are marked "Agreement" in Table 2. States conditioning their decision on a formal announcement by India and Bangladesh that Indian troops would be withdrawn (with an official timetable) are marked "Statement." One example was Italy, whose minimal requirement was that there should be some public commitment to withdrawal. Lo Prinzi (the chief of the Asian Desk in the Ministry of Foreign Affairs), initially said that "it would be helpful if, in the meantime, Mujib could announce a timetable for withdrawal." ${ }^{100}$ Later he explicitly conditioned recognition on withdrawal: "Lo Prinzi said the Foreign Ministry were now thinking of recommending that an appeal be made to Mujib to announce at least a timetable for withdrawal. If Mujib did this the Italians would have no difficulty in recognising earlier." ${ }^{101}$ By 3 February, the Italians had decided to "put off" recognition without "some withdrawal or engagement to withdraw Indian troops." 102 In the end, the Italians, along with the French, did not formally recognize Bangladesh until 12 February 1972, a few days

93. Telegram from FCO to Embassies, 29 January 1972, Premier's Archives, PREM 15/751.

94. Memo by Daunt, 31 December 1971, FCO 37/902.

95. Memo on Meeting between Vietnamese Ambassador and Tomlinson, 5 January 1972, FCO 37/1019.

96. Meeting Minutes, 20 December 1971, Defense and Overseas Policy Committee, Cabinet Office, DOP (71) 89, CAB 148/117.

97. Ibid.

98. Extract from 4th Cabinet Meeting (72), 27 January 1972, FCO 37/1025.

99. See, for example, Cable from Indian Embassy, 24 January 1972, FCO 37/1020.

100. Telegram from Hancock, 27 January 1972, FCO 37/1023.

101. Ibid.

102. Letter from Roper to Sutherland, 3 February 1972, FCO 37/1024. 
after the joint Indian-Bangladeshi troop withdrawal declaration on 8 February. Similarly, the Secretary-General of the Malaysian Ministry of Foreign Affairs said that it was "difficult for countries like Malaysia in absence of any move by Mujibur to make even a token reduction in the large Indian forces in Bangla Desh, or any positive statement about their withdrawal by the Indian Government." ${ }^{103}$ Canadian Prime Minister Pierre Trudeau asked Heath about withdrawal:

I wonder what the outcome has been of Mujib's intention, as described to you, that on his return to Dacca he would formally request the Indian Army's withdrawal in accordance with a phased and agreed plan. I recall a joint statement of January 9, the day before he returned, that the Indian forces would be withdrawn at the request of the Government of Bangla Desh but there was no timetable mentioned. If we and other countries could obtain firm information about such a plan, it would no doubt assist us in our evaluation of the situation. ${ }^{104}$

Canada did not recognize Bangladesh until 14 February, after the 8 February joint Indian-Bangladesh declaration on troop withdrawal.

Finally, some states required confirmation of the full withdrawal of Indian troops before recognizing. These are marked "Withdrawal." The sentiment was concisely stated by a senior Nigerian diplomat who explained that even though Indian assurances of withdrawal were assuring, they were not as assuring as withdrawal itself. ${ }^{105}$

The US's decision-making process was complicated by Nixon's secretly organized visit to China in early 1972. The State Department had recommended that the US "position on recognition will depend inter alia on a commitment on withdrawal of Indian forces and the ability of the Bangla Desh government to assume the responsibilities and obligations of a sovereign and independent state." ${ }^{106}$ Henry Kissinger also included as a reason for delaying recognition of Bangladesh that "we did not want to move too quickly in blessing the fruits of India's action ... In any case, Indian troops are scheduled to be withdrawn by March 25."107 Subsequently, at the explicit behest of the Chinese, ${ }^{108}$ Nixon and Kissinger delayed recognition until 4 April, after Nixon had returned from China.

103. Telegram from Johnston, 28 January 1972, FCO 37/1023.

104. Letter from Trudeau to Heath, 21 January 1972, PREM 15/751.

105. Telegram from Pickard, 1 February 1972, FCO 37/1024.

106. Paper Prepared in the Department of State, Foreign Relations of the US, Vol. E-7, 376. https:// history.state.gov/historicaldocuments/frus1969-76ve07/d376

107. Memorandum from the President's Assistant for National Security Affairs (Kissinger) to President Nixon, 16 February 1972, Foreign Relations of the US, Vol. E-7, 396. https://history.state.gov/historicaldocuments/frus1969-76ve07/d396

108. Memorandum of Conversation, 10 December 1971, Foreign Relations of the US, Vol. 11, 274. Available at <https://history.state.gov/historicaldocuments/frus1969-76v11/d274>. 


\section{Timing of Action and Policy}

For rhetorical adduction to be causally relevant to the policy at stake, the decision to support or adopt the policy should occur after the claimant has taken the action that legitimates the policy. As noted, states had three different types of action that they held to be a requirement for recognition. While not all states recognized Bangladesh after actual withdrawal had occurred, recognition decisions did follow the performance of the stated condition. For example, UK recognition followed Mujib's insistence that Indian troops were there with his agreement, Italian and Canadian recognition came after the joint declaration of a timetable for withdrawing troops, and Nigerian recognition followed the declaration of actual withdrawal.

\section{Alternative Explanations}

What are the alternative explanations for why there was initially such opposition to recognizing Bangladesh combined with subsequent widespread recognition? One alternative explanation is that states were inclined to recognize Bangladeshi independence as a result of the nature of the postelection pre-war violence in East Pakistan. However, the evidence runs counter to this possibility. The massacres by the West Pakistani forces (the case was made by the Indian parliament that this "amounts to genocide"), ${ }^{109}$ were known about, being widely reported in the mainstream press like the New York Times and The Sunday Times. ${ }^{110}$ However, this violence was simply not mentioned as a convincing reason for India's intervention. In fact, despite being well aware of their existence, no UN organ, like the Security Council or even the Sub-Commission on Prevention of Discrimination and Protection of Minorities or the Committee on Racial Discrimination, deliberately considered the massacres. ${ }^{111}$ Wheeler analyzes the rhetoric used during the war to justify and judge Indian intervention in the context of the massacres in East Pakistan being a "supreme humanitarian emergency." 112 He finds that despite recourse by India to humanitarian claims to classify its use of force as an exception to the rules, the society of states "emphatically rejected [those claims] as a legitimate basis for the use of force." 113 Instead, "the Indian action was widely viewed as a breach of the rules that jeopardized the pillars of interstate order."114 Bass's account of the telegram notifying the US government of the violence by the diplomat Archer Blood

109. Sydney H. Schanberg, "Parliament in India Condemns Pakistani 'Massacre' in East," New York Times, 1 April 1971, 1.

110. Sydney H. Schanberg, "Heavy Killing Reported," New York Times, 30 March 1971, 10; and Anthony Mascarenhas, "Genocide," The Sunday Times, 13 June 1971, 12-14.

111. Salzberg 1973, 116-20.

112. Wheeler 2000, 74.

113. Ibid., 71.

114. Ibid., 55. 
supports the claim that few held the violence a good reason for Indian intervention. Despite India's diplomatic efforts to rally support by citing the violence and the burden on India of the millions of refugees, other countries replied "with firm exhortations to avoid military confrontation with Pakistan." 115 Bass also argues that General Assembly resolution 2793 constituted a "worldwide repudiation of India's case for liberating Bangladesh." 116 Debnath's focused evaluation of the UK finds that despite some domestic pressure, the British government actively rejected a classification of the violence as genocide and she concludes that reports of atrocities played no role in decision making. ${ }^{117}$

Another alternative proposition is that there was an established set of rules, international law, that meant that there was no real need for contestation or argumentation (or rhetorical adduction), and the recognition of Bangladesh was merely a quasibureaucratic, rubber-stamp process of assessing whether the situation fit the criteria. Musson makes a related claim that "the British decision to recognize Bangladesh in early 1972 rested almost entirely on the fulfillment of international criteria." 118 However, this possibility assumes a much deeper institutionalization of the norms governing secession and aggression than was the case. By contrast, the existing international law on the issues of recognition, secession, and the use of force were not conducive to allowing Bangladesh to become a state. According to Crawford, the general law is clear: unlawful use of force cannot create sovereignty — cannot make secession legal. ${ }^{119}$ Shaw notes that Bangladesh is the only exception to the empirical rule that noncolonial secessions contrary to the consent of the mother state do not exist. ${ }^{120}$ Effective control was at the time, and still is, a key principle in international law relevant to recognition of states and governments. However, after World War II, there was a substantial shift in recognizing practice away from effective control and toward normative principles as legitimate reasons for recognition, primarily anticolonialism and self-determination. ${ }^{121}$ As Coggins finds, recognition of secessionist entities does not in fact follow a narrow interpretation of the international law principle of effective control and instead seems to vary according to the preferences of great powers, including legitimizing the violation of the norm of territorial integrity. ${ }^{122}$

The other action explained as being driven by rhetorical adduction is the adduced action, the withdrawal of troops. One alternative argument is that prompt withdrawal was a result of India facing the prospect of high occupation costs early on. This is not plausible because the inhabitants of East Pakistan were not resisting the Indian forces

115. Bass 2013, 140.

116. Ibid., 285.

117. Debnath 2011.

118. Musson 2008, 139.

119. Crawford 2007, 131-48. He cites Bangladesh as only a possible exception, in that it is "an entity created by external illegal force [that] could be genuinely independent in fact" (134).

120. Shaw 2003, 246.

121. Fabry 2010.

122. Coggins 2014. 
and frequently welcomed Indian troops as saving them from the violence directed against them by the West Pakistani military. ${ }^{123}$

Another alternative explanation is that Mujib wanted the troops to leave so that he would be less subject to pressure from the Indian government. In fact, the Mujib administration originally requested an Indian military presence, and invited Indian troops back into the country soon after withdrawal to assist the fledgling regime. Prior to Mujib's 8 January meeting with Heath, the Bangladeshi government position was that Indian army troops were essential to their plans. During a 6 January 1972 meeting between Indian government leaders, including Indira Gandhi and the Indian Defense Minister, Jagjivan Ram, and the Bangladeshi Foreign Minister Abdus Samad Azad, there was discussion of security issues. Ram "conveyed India's desire to recall Indian forces from Bangla Desh as soon as possible."124 Samad Azad resisted, emphasizing that "certain essential tasks still remain to be performed [by the] Indian Army." ${ }^{125} \mathrm{He}$ then requested and was granted "full assistance in training of officers and men of Bangla Desh forces."126

The alternative explanations are not supported by the evidence and the rhetorical adduction model provides the best explanation of the move to recognize Bangladesh. For many states, despite their initial objections, recognition of the new nation of Bangladesh was made acceptable by the withdrawal of Indian troops from Bangladesh. Britain, India, and Bangladesh argued successfully that withdrawal meant that recognition would not violate norms of non-aggression, self-determination, or the international legal norm of effective control of territory. So, both the withdrawal and many recognition decisions were driven by rhetorical adduction.

\section{Conclusion}

The rhetorical adduction model is applicable to a relatively specific set of conditions that come together to produce a particular process of argument, counterargument, adduced action, and policy adoption. If rhetorical adduction can bolster normative arguments, we should be interested in the conditions under which it works. What are some possible sources of variation in the operation of this mechanism?

A useful comparison to success in the Bangladesh case can be made with another set of arguments concerning the nonrecognition of Russia's annexation of the Crimean peninsula in 2014. The Crimean case is a useful comparison because it too involved arguments over territorial integrity, secession, and self-determination, as well as appeals to the international community for recognition. The question is why the primary argument deployed by Russia and Crimean separatists - that a

123. See Raghavan 2013; Sisson and Rose 1990.

124. Telegram from Garvey, 7 January 1972, PREM 15/751.

125. Ibid.

126. Ibid. 
referendum on the secession proved that it constituted self-determination-failed to gain any traction, even among relatively disinterested parties. As outlined earlier, a crucial element of rhetorical adduction is that, to be convincing, the actions taken to support the argument must be a competent performance, that is, in accordance with the intersubjectively accepted conception of the action.

The attempt to support the argument that the Crimean secession and annexation was an act of self-determination by holding a referendum was clearly incompetent. This is despite the fact that many of the inhabitants of Crimea are Russian speakers, Crimea was a sovereign state in 1917, an autonomous Soviet Socialist Republic from 1921 to 1945, part of Russia from 1945 to 1954, and an autonomous Republic within Ukraine from $1992 .{ }^{127}$ There was a potentially convincing argument to be made that transferal of Crimea from Ukraine to Russia was an act of self-determination. The Supreme Council of Crimea issued a declaration of independence on 11 March 2014 and subsequently held a referendum on whether Crimea should become part of Russia. ${ }^{128}$ Various Russian leaders, including Russian President Vladimir Putin during a telephone call to US President Barack Obama, asserted that the referendum was "legal and should be accepted." 129 The day after the referendum, Putin signed an executive order using the referendum as the sole justification for recognizing the Republic of Crimea. ${ }^{130}$ However, there were numerous objections to the referendum. Some of the most prominent concerned the form of the referendum (the questions, the timing, and its status under municipal law), the lack of independent election observers, the fact that intimidation and coercion were suspected because of the presence of armed Russian or pro-Russian forces, and doubts over the results. ${ }^{131}$ Numerous states and IOs claimed that the referendum's lack of validity supported their argument against recognition, including in a UNSC draft resolution vetoed by Russia

127. Adam Taylor, "To Understand Crimea, Take a Look Back at Its Complicated History," The Washington Post, 27 February 2014, <https://www.washingtonpost.com/news/worldviews/wp/2014/02/ 27/to-understand-crimea-take-a-look-back-at-its-complicated-history/>, accessed 6 September 2016.

128. "Crimea Parliament Declares Independence from Ukraine Ahead of Referendum," RT News, 13 March 2014, <http://rt.com/news/crimea-parliament-independence-ukraine-086>, accessed 6 September 2016.

129. "Crimea Votes to Secede from Ukraine in 'Illegal' Poll," The Guardian, 16 March 2014, <http://www. theguardian.com/world/2014/mar/16/ukraine-russia-truce-crimea-referendum>, accessed 6 September 2016.

130. It reads, in part, "Given the declaration of will by the Crimean people in a nationwide referendum held on March 16, 2014, the Russian Federation is to recognise the Republic of Crimea as a sovereign and independent state." See Executive Order on Recognizing the Republic of Crimea, 17 March 2014, available at <http://en.kremlin.ru/events/president/news/20596>, accessed 6 September 2016.

131. UK Ambassador to Ukraine, Simon Smith, summarized these objections. Simon Smith, "Why Should the Crimean Referendum Not Be Recognised?" [blog], 17 March 2014,<http://blogs.fco.gov.uk/ simonsmith/2014/03/17/why-should-the-crimean-referendum-not-be-recognised/>, accessed 6 September 2016. The result as reported by the organizers of the referendum was 96.77 percent in favor of reunification with Russia, and a turnout of 83.1 percent. However, in May, the Russian president's Human Rights Council released on its website a report, quickly withdrawn, that 50 to 60 percent voted for Russia with a voter turnout of 30-50 percent. See Paul Roderick Gregory, "Putin's 'Human Rights Council' Accidentally Posts Real Crimean Election Results," Forbes, 5 May 2014, <http://www.forbes.com/sites/ paulroderickgregory/2014/05/05/putins-human-rights-council-accidentally-posts-real-crimean-electionresults-only-15-voted-for-annexation/>, accessed 6 September 2016. 
(S/2014/189), as well as the General Assembly Resolution 68/262 on the Territorial Integrity of Ukraine. ${ }^{132}$

We can explain the failure of argumentation to change the normative status of the annexation of Crimea via the incompetent performance of the primary action taken as part of rhetorical adduction. An implication of this claim is that had the Crimean separatists made the referendum conform more closely to the intersubjective definition of a free and fair election, it would have been more convincing to the audience and much harder to dismiss by those implacably opposed to Russia's actions.

More speculatively, we can draw out several features of the situation that affect whether the full process of rhetorical adduction plays out. Only if the audience is valuable to the claimant and opposition is it worth trying to win their support. Only if the audience is relevant to the success of the policy will winning them over have any effect on whether the policy gets adopted. So, a source of variation is the value of the audience to the policy. The audience may vary in terms of how susceptible they are to a reframing of the situation. The more a situation is new or unprecedented, the more important rhetorical action is in constructing the properties of that situation, and hence the more consequential rhetorical adduction will be in bolstering the acceptability of a particular construction. Maybe there are principles at stake in the contestation. That is, some situations bear on questions that are relatively unsettled in society, where the norms and rhetorical commonplaces are relatively less taken for granted and hence more up for grabs. Another vital source of variation is the ability of the arguer and counterarguer to come up with socially sustainable arguments and counterarguments within the constraints of the intersubjective stock of background knowledge and rhetorical commonplaces. Scholars may be able to spend large amounts of time and effort coming up with plausible frames of situations, but the ingenuity of political actors in trying to construe events and ideas to their advantage is constantly surprising. The character and skill of individual people is another source of variation in the potential for rhetorical adduction both to be attempted and to be successful or otherwise.

I have proposed a specific type of mechanism through which normative argumentation can have a causal impact on important actions in international politics. In doing so, this article both adds to those already identified, for example, persuasion, rhetorical entrapment, and rhetorical coercion, and also provides avenues for further exploration of how rhetoric and argumentation shape the actions of states. By linking reason-based choice theory with argumentation theory, the article provides an enriched framework for understanding what effects argumentation can have and how it has them. Thus it both avoids obscuring argumentation's impact by limiting it to those rare situations of power- and interest-free truth seeking, and also allows for the detailed specification of other types of effects. While I have used the idea of changing an action's normative status, such as redefinition as an excused exception to a norm, there are plausibly many 
other ways of influencing the reasons for or against an action. There is much room for further research on this topic.

\section{References}

Adler, Emanuel, and Vincent Pouliot. 2011. International Practices. International Theory 3 (1):1-36.

Ariely, Dan, and Michael I. Norton. 2008. How Actions Create-Not Just Reveal-Preferences. Trends in Cognitive Sciences 12 (1):13-16.

Bass, Gary J. 2013. The Blood Telegram: Nixon, Kissinger, and a Forgotten Genocide. New York: Alfred A. Knopf.

Beach, Derek, and Rasmus Brun Pedersen. 2013. Process-Tracing Methods: Foundations and Guidelines. Ann Arbor: University of Michigan Press.

Benford, Robert D. 2011. Framing Global Governance from Below: Discursive Opportunities and Challenges in the Transnational Social Movement Arena. In Arguing Global Governance: Agency, Lifeworld, and Shared Reasoning, edited by Corneliu Bjola and Markus Kornprobst, 67-84. New York: Routledge.

Benford, Robert D., and David A. Snow. 2000. Framing Processes and Social Movements: An Overview and Assessment. Annual Review of Sociology 26 (1):611-39.

Bjola, Corneliu, and Markus Kornprobst, eds. 2011. Arguing Global Governance: Agency, Lifeworld, and Shared Reasoning. New York: Routledge.

Boltanski, Luc, and Laurent Thevenot. 1999. The Sociology of Critical Capacity. European Journal of Social Theory 2 (3):359-77.

2006. On Justification: Economies of Worth. Princeton, NJ: Princeton University Press.

Busby, Joshua W. 2007. Bono Made Jesse Helms Cry: Jubilee 2000, Debt Relief, and Moral Action in International Politics. International Studies Quarterly 51 (2):247-75.

Coggins, Bridget. 2014. Power Politics and State Formation in the Twentieth Century: The Dynamics of Recognition. New York: Cambridge University Press.

Crawford, Neta. 2002. Argument and Change in World Politics: Ethics, Decolonization, and Humanitarian Intervention. Cambridge, UK: Cambridge University Press.

Crawford, James. 2007. The Creation of States in International Law. 2nd ed. Oxford, UK: Clarendon Press.

Debnath, Angela. 2011. British Perceptions of the East Pakistan Crisis 1971: "Hideous Atrocities on Both Sides"? Journal of Genocide Research 13 (4):421-50.

Deitelhoff, Nicole. 2009. The Discursive Process of Legalization: Charting Islands of Persuasion in the ICC Case. International Organization 63 (1):33-65.

Dietrich, Franz, and Christian List. 2011. A Model of Non-Informational Preference Change. Journal of Theoretical Politics 23 (2):145-64.

2013. A Reason-Based Theory of Rational Choice. Nous 47 (1):104-34.

Elster, Jon. 1998. Deliberation and Constitution Making. In Deliberative Democracy, edited by Jon Elster, 97-122. Cambridge, UK: Cambridge University Press.

Fabry, Mikulas. 2010. Recognizing States: International Society and the Establishment of New States Since 1776. Oxford, UK: Oxford University Press.

Fearon, James D. 1997. Signaling Foreign Policy Interests: Tying Hands Versus Sinking Costs. Journal of Conflict Resolution 41 (1):68-90.

Finnemore, Martha, and Kathryn Sikkink. 1998. International Norm Dynamics and Political Change. International Organization 52 (4):887-917.

Goldgeier, James M., and Philip E. Tetlock. 2001. Psychology and International Relations Theory. Annual Review of Political Science 4 (1):67-92.

Goldsmith, Jack, and Eric Posner. 2002. Moral and Legal Rhetoric in International Relations: A Rational Choice Perspective. Journal of Legal Studies 31 (S1):S115-S139. 
Grant, Thomas D. 2015. Aggression Against Ukraine: Territory, Responsibility, and International Law. New York: Palgrave Macmillan.

Hanrieder, Tine. 2011. The False Promise of the Better Argument. International Theory 3 (3):390-415. Hart, H.L.A. 1994. The Concept of Law. Oxford, UK: Clarendon Press.

Jervis, Robert. 1970. The Logic of Images in International Relations. New York: Columbia University Press.

Johnstone, Ian. 2003. Security Council Deliberations: The Power of the Better Argument. European Journal of International Law 14 (3):437-80.

Kornprobst, Markus. 2014. From Political Judgments to Public Justifications (and Vice Versa): How Communities Generate Reasons Upon Which to Act. European Journal of International Relations 20 (1):192-216.

Krebs, Ronald R., and Patrick T. Jackson. 2007. Twisting Tongues and Twisting Arms: The Power of Political Rhetoric. European Journal of International Relations 13 (1):35-66.

Kuhn, Deanna. 1991. The Skills of Argument. Cambridge, UK: Cambridge University Press.

Kux, Dennis. 1994. Estranged Democracies: India and the United States 1941-1991. New Delhi: Sage. McDermott, Rose. 2001. The Psychological Ideas of Amos Tversky and Their Relevance For Political Science. Journal of Theoretical Politics. 13 (1):5-33.

Mearsheimer, John. 2011. Why Leaders Lie: The Truth About Lying in International Politics. Oxford, UK: Oxford University Press.

Mercier, Hugo, and Dan Sperber. 2011. Why Do Humans Reason? Arguments For an Argumentative Theory. Behavioral and Brain Sciences 34 (2):57-74.

Mor, Ben D. 2012. Credibility Talk in Public Diplomacy. Review of International Studies 38 (2):393-422.

Müller, Harald. 2004. Arguing, Bargaining and All That: Communicative Action, Rationalist Theory and the Logic of Appropriateness in International Relations. European Journal of International Relations 10 (3):395-435.

Musson, Janice. 2008. Britain and the Recognition of Bangladesh in 1972. Diplomacy and Statecraft 19 (1): $125-44$.

Nyhan, Brendan, and Jason Reifler. 2010. When Corrections Fail: The Persistence of Political Misperceptions. Political Behavior 32 (2):303-30.

Raghavan, Srinath. 2013. 1971: A Global History of the Creation of Bangladesh. Cambridge, MA: Harvard University Press.

Reiter, Dan. 2012. Democracy, Deception, and Entry into War. Security Studies 21 (4):594-623.

Risse, Thomas. 2000. "Let's Argue!" Communicative Action in World Politics. International Organization 54 (1): $1-40$.

- 2004. Global Governance and Communicative Action. Government and Opposition 39 (2): 288-313.

Risse, Thomas, Stephen C. Ropp, and Kathryn Sikkink, eds. 1999. The Power of Human Rights: International Norms and Domestic Change. Cambridge, UK: Cambridge University Press.

Salzberg, John. 1973. UN Prevention of Human Rights Violations: The Bangladesh Case. International Organization 27 (1):115-27.

Sartori, Anne. 2005. Deterrence by Diplomacy. Princeton, NJ: Princeton University Press.

Schelling, Thomas C. 1960. The Strategy of Conflict. Cambridge, MA: Harvard University Press.

Schimmelfennig, Frank. 2001. The Community Trap: Liberal Norms, Rhetorical Action, and the Eastern Enlargement of the European Union. International Organization 55 (1):47-80.

Searle, John. 2010. Making the Social World. New York: Oxford University Press.

Sell, Susan K., and Aseem Prakash. 2004. Using Ideas Strategically: The Contest Between Business and NGO Networks in Intellectual Property Rights. International Studies Quarterly 48 (1):143-75.

Seymour, Lee. 2014. Let's Bullshit! Arguing, Bargaining and Dissembling Over Darfur. European Journal of International Relations 20 (3):571-95.

Shafir, Eldar, Itamar Simonson, and Amos Tversky. 1993. Reason-based Choice. Cognition 49 (1):11-36. Shannon, Vaughn P. 2000. Norms Are What States Make of Them: The Political Psychology of Norm Violation. International Studies Quarterly 44 (2):293-316. 
Shannon, Vaughan P., and Paul A. Kowert, eds. 2011. Psychology and Constructivism in International Relations: An Ideational Alliance. Ann Arbor: University of Michigan Press.

Shaw, Malcolm. 2003. The Role of Recognition and Non-Recognition with Respect to Secession: Notes on Some Relevant Issues. In Secession and International Law: Conflict Avoidance-Regional Appraisals, edited by Julie Dahlitz, 243-58. New York: United Nations.

Simonson, Itamar. 1989. Choice Based on Reasons: The Case of Attraction and Compromise Effects. Journal of Consumer Research 16 (2):158-74.

Sisson, Richard, and Leo E. Rose. 1990. War and Secession: Pakistan, India, and the Creation of Bangladesh. Berkeley: University of California Press.

Slovic, Paul. 1995. The Construction of Preference. American Psychologist 50 (5):364-71.

Snow, David A., R. Burke Rochford Jr., Steven K. Worden, and Robert D. Benford. 1986. Frame Alignment Processes, Micromobilization, and Movement Participation. American Sociological Review 51 (4):464-81.

Toulmin, Stephen. 2003. The Uses of Argument. UK: Cambridge University Press.

Tversky, Amos, Shmuel Sattath, and Paul Slovic. 1988. Contingent Weighting in Judgment and Choice. Psychological Review 95 (3):371-84.

Ulbert, Cornelia, and Thomas Risse. 2005. Deliberately Changing the Discourse: What Does Make Arguing Effective? Acta Política 40 (3):351-67.

United Nations Security Council. 1971. Official Record 1971. New York: United Nations.

US Department of State. 2005. Foreign Relations of the United States, 1969-1976, Vol. 11, South Asia Crisis, 1971. Washington, DC: US Government Printing Office.

2005. Foreign Relations of the United States, 1969-1976, Vol. E-7, Documents on South Asia 1969-1972. Washington, DC: US Government Printing Office.

Vlaev Ivo, Nick Chater, Neil Stewart, and Gordon D.A. Brown. 2011. Does the Brain Calculate Value? Trends in Cognitive Sciences 15 (11):546-54.

Watson, Scott D. 2012. "Framing" the Copenhagen School: Integrating the Literature on Threat Construction. Millennium 40 (2):279-301.

Wheeler, Nicholas. 2000. Saving Strangers: Humanitarian Intervention in International Society. New York: Oxford University Press. 